\title{
Hacia una propuesta de enseñanza interdisciplinaria en el ciclo básico de las carreras de grado en Ciencias Económicas
}

\author{
Towards an Interdisciplinary Teaching Proposal for the \\ Basic Core Curriculum in Bachelor's Degrees in Economics \\ Rumo a uma proposta de ensino interdisciplinário no ciclo básico dos \\ cursos de grau dem Ciências Econômicas
}

\section{Leila Di Russo}

Facultad de Ciencias Económicas, Universidad Nacional del Litoral, Argentina

E-mail: Ihauque@yahoo.com.ar

Fecha de recepción: 21/06/2019 Fecha de aceptación: 08/06/2020

\section{Resumen}

El presente trabajo rescata algunos resultados obtenidos en el proceso de investigación realizadopara la elaboración de una tesis denominada «Secuencias de enseñanza para la articulación de disciplinas en el ciclo básico común de la FCE-UNL», que ha sido presentadaen el marco de la Maestría en Docencia Universitaria perteneciente a la Facultad de Humanidades y Ciencias de la UNL.Del mismo se han extraído algunos delos trabajos de contrastación y búsqueda de evidencias empíricasy sus resultados, los quepermitieron analizar la formación actual de los alumnos al culminar el ciclo básico común en la FCE.

Las prácticas educativas universitarias que se observan en los trayectos vigentes, tienden muchas veces a «reducir» la necesaria integralidad del conocimiento.Para relevar la visión de los docentes se utilizaron entrevistas.Fueron semiestructuradas, realizadas en profundidad, en forma personal y directa, conteniendo un cuestionario base que sirvió de disparador para la indagación.

La interacción permanente con los estudiantes del Ciclo de Formación

Palabras clave

- interdisiciplina

- enfoque sistémico

- articulación
Básica Común demostró momento a momento que se requería un abordaje sistémico para comprender, no solamente las cuestiones que permiten construir a un profesional para su futuro desempeño, sino también y espe- 
Keywords

- interdiscipline

- systemic approach

- coordination cialmente para enfrentar al mundo y a la vida con un conjunto coherente de valores que surjan de una formación integral digna de la Universidad Pública Argentina.

\begin{abstract}
This work reviews some outcomes from the research process carried out for the thesis "Teaching sequences for the coordination of disciplines in the basic core curriculum of FCE-UNL", written within the framework of the Master's in University Teaching from FHUC-UNL. Some contrastive works and some other works based on the search for empirical evidence were taken from the thesis mentioned and they allowed researchers to analyse the current state of training of those students who finished the Basic Core Curriculum stage in FCE.

Many times, current university education practices tend to "downplay" the importance of viewing knowledge as a whole. Teachers were asked to participate in surveys to gather information about their view. These were semi-structured, carried out in person and directly, and consisted in a questionnaire which triggered a deeper inquiry.

Constant interaction with students from the Basic Core Curriculum years showed the need for a systemic approach in order to understand not only the issues related to the training of professionals for their future performance but also -and mainly- in order to prepare them to face the world and life in general with a consistent set of beliefs reinforced during their comprehensive training in the Argentinian Public University.
\end{abstract}

\section{Resumo}

0 presente trabalho resgata alguns resultados obtidos no processo de pesquisa realizado para a elaboração de uma tese chamada "Sequências de ensino para a articulação de disciplinas no ciclo básico comum da FCE-UNL", que tem sido apresentada dentro do quadro do Mestrado em Docência Universitária pertencente à Faculdade de Humanidades e Ciências da UNL. Do mesmo tem se extraído alguns dos trabalhos de contrastação e busca de evidências empíricas e seus resultados, os que permitiram analisar a formação atual dos alunos ao finalizarem 0 ciclo básico comum na FCE.

As práticas educacionais universitárias que se observam nos trajetos vigentes, muitas vezes têm tendência a "reduzir" a necessária integralidade do conhecimento. Para relevar a visão dos docentes utilizaram-se entrevistas. Foram semi-estruturadas, realizadas em profundidade, em forma pessoal e direta, contendo um questionário base que serviu de disparador para a indagação.

A interação permanente com os estudantes do Ciclo de Formação Básica

- abordagem sistémica

- articulação

Comum demonstrou a cada instante que era necessária uma abordagem 
Di Russo / Hacia una propuesta de enseñanza...

sistémica para compreender, nem só as questões que permitem construir a um profissional para seu futuro desempenho, mas também e especialmente para defrontar ao mundo e à vida com um conjunto coerente de valores que surjam de uma formação integral digna da Universidade Pública Argentina. 